\title{
Spatial analysis of elder abuse in a Brazilian municipality
}

\author{
Análise espacial da violência contra idosos em um município brasileiro \\ Análisis espacial de la violencia contra el adulto mayor en un municipio brasileño
}

Rosalina Aparecida Partezani Rodrigues' ORCID: 0000-0001-8916-1078

Francisco Chiaravalloti-Neto" ORCID: 0000-0003-2686-8740

Jack Roberto Silva Fhon" ORCID: 0000-0002-1880-4379

Alisson Fernandes Bolina"l ORCID: 0000-0002-1364-0176

' Universidade de São Paulo. Ribeirão Preto, São Paulo, Brazil. "Universidade de São Paulo. São Paulo, São Paulo, Brazil. I" Universidade de Brasília. Brasília, Distrito Federal, Brazil.

How to cite this article: Rodrigues RAP, Chiaravalloti-Neto F, Fhon JRS, Bolina AF. Spatial analysis of elder abuse in a Brazilian municipality. Rev Bras Enferm. 2021;74(Suppl 2):e20190141. doi: http://dx.doi.org/10.1590/0034-7167-2019-0141

Corresponding author: Rosalina Aparecida Partezani Rodrigues E-mail: rosalina@eerp.usp.br

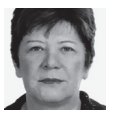

EDITOR IN CHIEF: Dulce Barbosa ASSOCIATE EDITOR: Andrea Bernardes

Submission: 07-16-2019

Approval: 09-07-2020

\begin{abstract}
Objective: to analyze the spatial distribution of elder abuse in Ribeirão Preto-SP, according to victims' place of residence and event. Method: an ecological study that analyzed 1,153 elder abuse police reports (2009 to 2013). Local gross and empirical Bayesian rates and Local Moran's I were calculated. Results: there was a heterogeneous distribution of concentration of sectors with a high incidence rate surrounded by neighbors with also high rates, considering place of residence. In contrast, analysis by place of occurrence showed a greater concentration in the central areas of the municipality. More than $80 \%$ of cases of violence occurred at their own homes and with spatial dependence on distribution by occurrence up to a 5,000 m distance from their places of residence. Conclusion: data reinforce that violence is a complex phenomenon, affecting several social strata, including in central urban areas and in elderly people families' own context.
\end{abstract}

Descriptors: Aged; Violence; Elder Abuse; Spatial Analysis; Geographic Mapping.

\section{RESUMO}

Objetivo: analisar a distribuição espacial da violência contra idosos em Ribeirão Preto - SP, segundo local de residência da vítima e de ocorrência do evento. Método: estudo ecológico, que analisou 1.153 Boletins de Ocorrência de violência contra idosos (2009 a 2013). Foram calculadas taxas bruta e bayesiana empírica local e Índice Moran local. Resultados: evidenciouse uma distribuição heterogênea da concentração de setores com alta taxa de incidência circundados por vizinhos com taxas também elevadas, considerando o local de residência. Em contrapartida, a análise por local de ocorrência demonstrou maior concentração nas áreas centrais do município. Mais de $80 \%$ dos casos de violência ocorreram nos próprios domicílios e com dependência espacial da distribuição por ocorrência até uma distância de $5.000 \mathrm{~m}$ do local de residência. Conclusão: os dados reforçam o fato da violência ser fenômeno complexo, que acomete diversas camadas sociais, inclusive em áreas centrais urbanas e no próprio contexto familiar do idoso.

Descritores: Idoso; Violência; Maus-Tratos ao Idoso; Análise Espacial; Mapeamento Geográfico.

\section{RESUMEN}

Objetivo: analizar la distribución espacial de la violencia contra los adultos mayores en Ribeirão Preto - SP, según el lugar de residencia de la víctima y lugar del evento. Método: estudio ecológico, que analizó 1.153 denuncias de violencia contra el adulto mayor (2009 a 2013). Se calcularon las tasas bayesianas crudas y empíricas locales y el índice de Moran local. Resultados: hubo una distribución heterogénea de la concentración de sectores con alta tasa de incidencia rodeados de vecinos con tasas también altas, considerando el lugar de residencia. En contraste, el análisis por lugar de ocurrencia mostró una mayor concentración en las áreas centrales del municipio. Más del $80 \%$ de los casos de violencia ocurrieron en el propio domicilio y con dependencia espacial de la distribución por ocurrencia hasta una distancia de $5.000 \mathrm{~m}$ del lugar de residencia. Conclusión: los datos refuerzan el hecho de que la violencia es un fenómeno complejo, que afecta a varios estratos sociales, incluso en las zonas urbanas centrales y en el propio contexto familiar de los adultos mayores.

Descriptores: Anciano; Violencia; Maltrato al Anciano; Análisis Espacial; Mapeo Gráfico. 


\section{INTRODUCTION}

Violence is a global social concern that affects the health and human rights of millions of elderly people worldwide ${ }^{(1)}$. It is considered a public health problem that deserves attention from the international community, as it contributes to increased morbidity, mortality, institutionalization and hospital admission, with a negative impact on the family and society ${ }^{(2)}$.

Conceptually, "violence is a public health challenge defined by the intentional use of physical force or power, threatened or actual, against oneself, another person, or against a group or community, that either results in, or has a high likelihood of, resulting in injury, death, psychological harm, maldevelopment or deprivation"(2). It is classified as physical, psychological, sexual, financial, neglect, self-neglect and abandonment ${ }^{(3)}$.

In order to identify elder abuse prevalence in the scientific literature, Yon et. al. ${ }^{(4)}$ summarized the results of 52 studies carried out in 28 countries and identified a prevalence of general violence estimated at $15.7 \%$, distributed as psychological (11.6\%), financial (6.8\%), negligence (4.2\%), physical $(2.6 \%)$ and sexual (0.9\%). In Brazil, although there are no exact figures on this type of event, a study based on data from DATASUS identified 930,805 hospitalizations of elderly people due to external causes, 16,814 of them due to aggression and attended to in an urgent or elective manner ${ }^{(5)}$. Studies on elder abuse conducted in some cities identified a prevalence of $20.9 \%$ in Uberaba, Minas Gerais ${ }^{(6)}$, and $13 \%$ in Florianópolis, Santa Catarina ${ }^{(7)}$.

The Brazilian Ministry of Health recommends that Geographic Information Systems (GIS) be integrated into the Cartography Department of the Brazilian Institute of Geography and Statistics $^{(8)}$ so that they can be used to control, assess and help fight epidemics, analyze urbanization and the environment, assessment of health services and their correlation with the health of populations ${ }^{(9)}$. This would allow for important causal relationships and, therefore, the identification and characterization of decision-making relationships for assisting the population ${ }^{(10)}$.

There has been a significant increase in violence and crime worldwide. To control the progress of these phenomena, police forces have used $\mathrm{GIS}^{(11)}$ as a tool for collecting, storing, retrieving and displaying georeferenced data from the real world, in addition to allowing to propose hypotheses for certain phenomena ${ }^{(12)}$.

In several countries, elder abuse is an underreported event, both by the victim and by third parties. Studies have highlighted the importance of mapping this phenomenon as a control tool in urban spaces by the agencies responsible ${ }^{(13-14)}$. However, these surveys were not carried out specifically with the elderly population.

Using GIS and spatial analysis can contribute to visualization and better understanding of the spatial pattern of elder abuse behavior in the municipality under study, in addition to providing subsidies for managing intersectoral public policies, in partnership with social justice and health sectors. Thus, once these areas are identified, it will be up to the Primary Care health professionals to outline action plans to prevent and combat this event in their respective areas of coverage.
Given the above, the present study aims to analyze the spatial distribution of elder abuse in the city of Ribeirão Preto - SP, according to victims' places of residence and event occurrence.

\section{METHODS}

\section{Ethical aspects}

This study was approved by Ribeirão Preto's Police Station, Elder Abuse Department, and by the Research Ethics Committee of Escola de Enfermagem de Ribeirão Preto at Universidade de São Paulo (USP).

\section{Design, place of study and period}

This ecological study was carried out in Ribeirão Preto, in northeastern São Paulo, whose population was estimated in the last census (2010) at 604,682 inhabitants, 75,763 of whom were elderly ${ }^{(15)}$. The city's economy is based on sugar cane cultivation, processing plants and service provision, being considered an educational pole of the state and the country. As for the territory and environment, the municipality has $98.4 \%$ of households with adequate sewage. Moreover, $92.5 \%$ and $64.5 \%$ of urban households on public roads have, respectively, afforestation and adequate urbanization (presence of manhole, sidewalk, pavement and curb) ${ }^{(15)}$.

\section{Population or sample; inclusion and exclusion criteria}

Participants in the study were elderly people who suffered violence and registered this event in police reports at Ribeirão Preto's Police Station, Elder Abuse Department, from 2009 to 2013. To select police reports, we adopted the following inclusion criteria: elderly people aged over 60 years old, of both sexes and living in the urban area of Ribeirão Preto. We emphasize that the chronological age limit for being considered elderly in Brazil is 60 years or more, as provided by law ${ }^{(16)}$, this being the reference adopted in this study.

\section{Study protocol}

Data collection took place from 2015 to 2017 and was conducted by undergraduate, graduate students and researchers previously trained by the study coordinator. Police reports of elderly victims of abuse were consulted. Data were recorded on an instrument containing the variables: sex (male and female), age (60 to $69 ; 70$ to 79 ; and 80 and over), marital status (married, widowed, divorced/separated/judiciously separated, single, common-law marriage), education (illiterate, incomplete high school, complete high school, incomplete high school, complete high school, incomplete college, complete college), retired (yes and no), as well as victims' home addresses and occurrence of violence.

Of the 1,177 cases of violence that met the eligibility criteria, 13 were discarded because they did not have the victim's full address and 11 because they were located in another municipality. Therefore, the sample was completed in 1,153 cases of violence. 


\section{Analysis of results, and statistics}

To characterize elderly victims of violence according to socioeconomic and demographic variables, we used descriptive statistical analysis, with absolute and percentage frequency distribution. Incidence rates were calculated using the following formula: $\mathrm{TX}=$ number of cases $* 100,000 /$ (population aged 60 or over), with the numbers of cases grouped for the entire municipality, according to census tracts. Incidence rates at the municipal level were calculated by sex, age, marital status and education.

For spatial analysis, we first performed the geocoding of cases of violence by location of both victims' residence and event occurrence using the Google Earth program. Thus, for each of them, the geographic coordinates were obtained in the LatLong and Datum WGS84 system. Subsequently, these data were transformed to Universal Transverse Mercator (UTM) coordinates zone 22 Datum SAD69.

The census tracts defined by the 2010 Demographic Census ${ }^{(15)}$ were considered units of analysis. There were, in Ribeirão Preto, a total of 988 sectors classified as urban, of which 18 were eliminated because they were outside the urban area borders, despite being classified as such, and 970 census tracts were included in this study. However, of this total, seven sectors did not contain a population and, therefore, were added to the adjacent ones, so that the study included 963 units of analysis.

To calculate the incidence rate, we counted the cases of violence by place of residence, according to the urban census tracts in the municipality under study; this, together with population information, made it possible to calculate incidence rates by census tracts. Considering the small numbers of inhabitants of the units of analysis, the possibility of underreporting and the tendency of closer neighbors or who share the same geographical boundary to present similar characteristics, we calculated the local empirical Bayesian rate to smooth out random fluctuations, since they consider not only the information of a single area, but also the data of its neighborhood ${ }^{(17)}$. Terraview, version 4.2.2 was used to carry out the analyzes.

To calculate incidence rates by place of residence according to the census tracts, we used Local Moran's I to identify sectors with high (low) rates surrounded by others also with high (low) rates. These are the so-called high-high and low-low, which were used to identify clusters of high and low risk for elder abuse according to residence. To compare these results with violence according to place of occurrence, all cases were also geocoded by place of occurrence, which allowed calculate the number of records per $\mathrm{km}^{2}$ for census tracts. Then, Local Moran's I was also used to identify sectors with high (low) values of occurrences of violence per $\mathrm{km}^{2}$ surrounded by others with high (low) values.

To test the spatial randomness of the point distribution of cases of violence by place of occurrence and place of residence, we used the univariate Ripley's K function. To test the spatial randomness between the two distributions, we use the bivariate Ripley's K function. This function generates, in each situation, a graph of values according to the distance and the respective $95 \%$ confidence intervals. If the graph generated falls within the confidence interval limits, randomness is identified; and, if it exceeds the upper limit of the interval, it characterizes spatial dependence.

Maps of the local gross and Bayesian rate distributions, as well as Local Moran's I, were built using the TerraView program, and geocoding was performed via Google Earth. Thematic maps were elaborated in QGIS, version 2.12, and Ripley's k function applied through $\mathrm{R}$, version 3.4.1.

\section{RESULTS}

Of the 1,153 police reports analyzed, $56.2 \%$ were recorded by female victims and $43.8 \%$ male, and incidence $(100,000$ inhabitants) was 1446.33 and 1604.96 , respectively. Regarding age, the average was 70.55 years $(70.12-70.97) ; \pm 7.39 ; 95 \% \mathrm{Cl}$. Elderly people were categorized into age groups: 60-69, 558 (48.40\%); $70-79,431$ (37.38\%); 80 or more, 160 (13.88\%); and without information, $4(0.35 \%)$. Incidences in the three age groups analyzed were $1352.46,1825.19$ and 1404.00 per 100 thousand inhabitants/year.

In the marital status category, victims without a partner figured prominently, 597 (51.80\%), with an incidence of 2937.27 per 100 thousand inhabitants/year, followed by those with a partner, 498 (43.2\%), incidence of 2796.34, and without information, 58 (5\%).

As for education, the category was composed of 195 (16.91\%) illiterates and with incomplete primary education; with incomplete high school, 510 (44.23\%); with complete high school/incomplete higher education, 122 (10.58\%); with complete higher education, 96 (8.33\%); and without information, 230 (19.95\%). Concerning incidence, we identified the following distribution: illiterate and with incomplete primary education totaled 100.16; with incomplete high school, 526.12; with complete high school/incomplete higher education, 81.94; with complete higher education, 111.70; and without information, 6736.97 . On the other hand, there was a predominance of 676 (58.63\%) elderly people who had no retirement; with retirement, 314 (27.23\%); and without information, 163 (14.14\%).
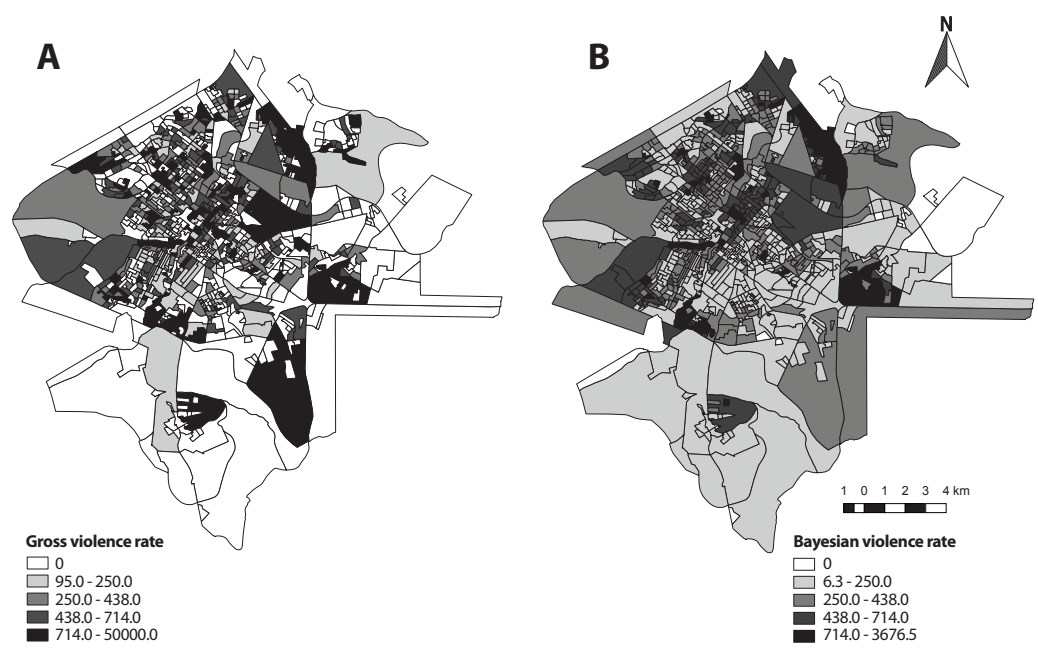

Figure 1 - Gross elder abuse rate (A) and Bayesian rate (B) maps per 100 thousand inhabitants/year, Ribeirao Preto, São Paulo, Brazil (2009-2013) 

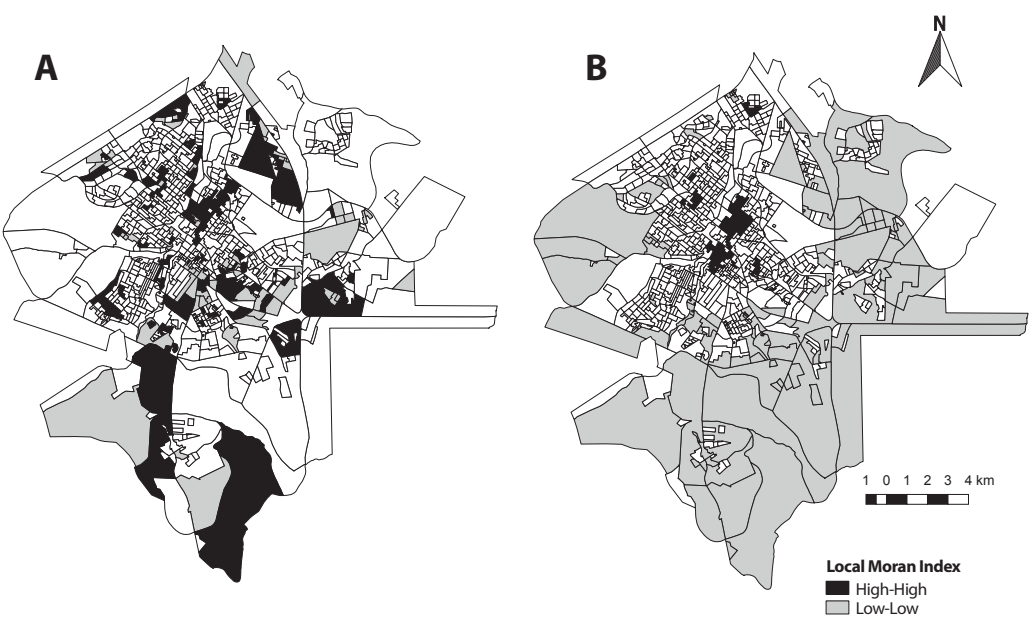

Figure 2 - Spatial distribution of elder abuse map according to Moran's I by place of residence (A) and occurrence (B), Ribeirão Preto, São Paulo, Brazil (2009 - 2013).

A) Violence by place of occurrence

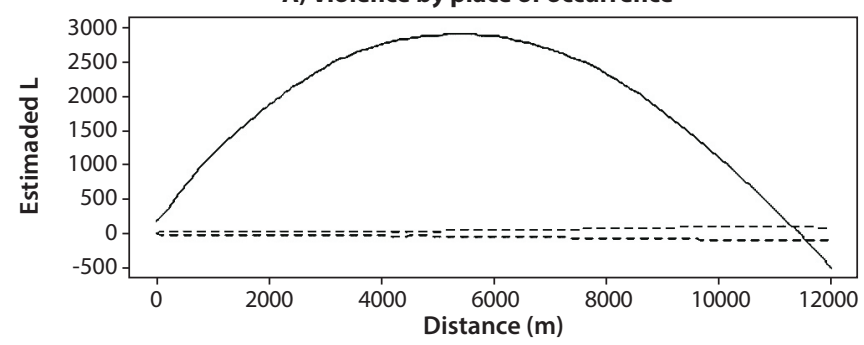

B) Violence by place of residence

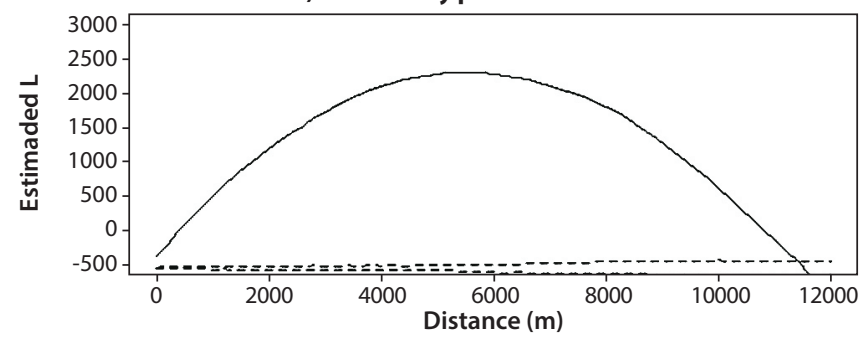

C) $\mathrm{K}$ bivariate function

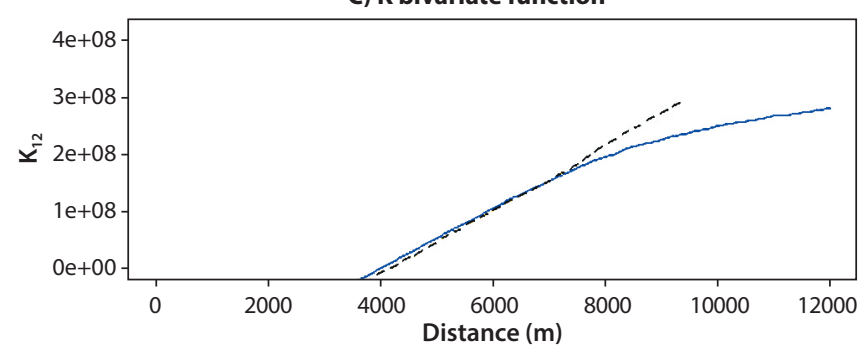

Figure 3 - Elder abuse case distribution by place of residence and occurrence, according to the univariate Ripley's K function, Ribeirão Preto, São Paulo, Brazil (2009 - 2013)

Figure 1 shows elder abuse rates (per 100,000 inhabitants/ years) according to census tracts, whereas in section $1 \mathrm{~A}$ the gross rate is described and, in 1B, the Bayesian rate. It is noted that the smoothing by means of a local empirical Bayesian rate showed a reduction in the number of areas with zero rates and a decrease in the upper limit of the rates, from 50000.00 to 3676.5 (per 100 thousand inhabitants/years).
In Figure 2, Moran's I map by place of residence $(A)$ shows a heterogeneous concentration of sectors with a high incidence rate of violence surrounded by neighbors with high rates (high-high), including areas peripheral. In contrast, in Moran's I analysis by place of occurrence $(B)$, this same condition was evidenced especially in the central areas of the municipality. Areas of low incidence were also observed with neighborhoods that also presented low values (low-low), with greater concentration of this event in peripheral regions.

We verified, conducting an analysis of the list of cases by place of occurrence and residence, that of the 1,141 elder abuse events, more than $80 \%$ occurred at their homes. Only 4\% suffered violence more than 5,000 m away from their homes (Table 1). '

The univariate Ripley's K function results assess the spatial distribution of cases of violence by places of occurrence (Graph A) and residence (Graph B). We found that both presented an aggregate pattern up to a distance of 11,000 meters, with peaks (maximum aggregation) occurring at an approximate distance of 5,000 meters. We also verified that, in graph $C$, the punctual distribution of cases by occurrence showed spatial dependence in relation to distribution by place of residence up to a distance of 5,000 m (Figure 3).

Table 1 - Elder abuse distribution according to distance between places of residence and place of occurrence, Ribeirão Preto, São Paulo, Brazil $(2009-2013)$

\begin{tabular}{lcc}
\hline Distância $(\mathbf{m})$ & $\mathbf{n}$ & $\%$ \\
\hline 0 (same address) & 919 & 80.5 \\
2 to less than 100 & 19 & 1.7 \\
100 to less than 200 & 14 & 1.2 \\
200 to less than 500 & 19 & 1.7 \\
500 to less than 1000 & 28 & 2.5 \\
1000 to less than 2000 & 33 & 2.9 \\
2000 to less than 5000 & 68 & 6.0 \\
5000 to 13557 & 41 & 4.0 \\
Total & 1141 & 100.0 \\
\hline
\end{tabular}

\section{DISCUSSION}

In this study, we found a higher incidence rate of elder abuse in males and in those aged 60-69 years. In Mexico, research also found that violence was more frequent in elderly males, but also among younger people, aged 60 to 64 years ${ }^{(18)}$. However, a systematic literature review found that it affects one in six older elderly people, i.e., approximately 141 million people aged 80 and over in the world suffer some form of abuse ${ }^{(4)}$.

The study of violence is complex due to the diverse populations affected, the operational definitions and the different research methods ${ }^{(19)}$, which also explains data diversity. Elder abuse is known to present itself differently between sexes, and this reiterates the need to know the dynamics of its social determinants, particularly with regard to the educational and cultural role among men ${ }^{(18)}$. 
Another aspect that makes it difficult to study this phenomenon is underreporting, especially when offenders are family members. In this context, little is known about the true extent of violence, the most prevalent forms, the triggering and risk factors, the distinctive characteristics of offenders and the consequences for elderly victims ${ }^{(20)}$.

In this light, a surprising fact was evidenced in this study: the highest rate of notification of violence refers to cases that occurred at elderly people's homes. In this regard, eventually inactive elderly people with few options for family and social support end up not having their inherent care needs fulfilled regarding senescence and senility. Another factor associated with family violence is lack of social, economic and social support structure, as this generates conflicts among family members, with elderly people being particularly affected as they are more vulnerable.

Despite not being analyzed in this study, many reports of elder abuse involved abuse of illicit drugs and alcohol by a family member, especially children or grandchildren ${ }^{(21)}$.

Although most of reports in this study pointed to occurrence of violence at their homes, we know that only a small portion of victims seek protection services ${ }^{(22)}$. Violence concealment results mainly from the fear of possible conflicts and shame of elderly people in the face of this condition. Another barrier involves elderly people in situations of physical and cognitive vulnerabilities, typical of senescence and senility ${ }^{(23)}$, which hinder access to legal protection mechanisms.

These data support the results of this study when analyzing the spatial distribution of elder abuse rates, as well as Moran's I by place of occurrence, as both indicated a predominance of records in the central areas of Ribeirão Preto. Violence is a phenomenon that affects several social strata, including urban centers. Although most cases occur at elderly people's homes, during data collection, we observed records of violence also in public transportation and public/private places such as banks, supermarkets, health services, among others. With the police station being close to the central region of Ribeirão Preto favors the formalization of complaints, mainly because it is a population that may present difficulties for urban mobility. Moreover, even though the media divulges the importance of registering violence, elderly people living in the periphery can be considered mostly with less education, which makes access to information and knowledge of the safety net and their rights more difficult.

However, Moran's I data by place of residence shows highrisk spatial clusters throughout the municipality, including in peripheral areas. Research carried out in different American cities through geoprocessing showed a considerable increase in this phenomenon in peripheries, as evidenced in this study. The authors point out lack of research to investigate how elderly people experience violence and its consequences and how this experience can change their lives and compromise their autonomy ${ }^{(24)}$.

In the international and national literature, few studies have performed the spatial analysis of elder abuse records, which makes it difficult to discuss these data. An analysis of this type with the general population, carried out in the United States, assessed 3,109 records of intentional traumatic violence. It verified, by Moran's I, four main areas with significant grouping of incidents of this event, being related to the lack of education, among other factors ${ }^{(25)}$. Specifically with the elderly population, a household survey carried out in a Brazilian municipality using the Kernel estimate identified that the areas with the lowest concentration of income and low education were the most affected by violence ${ }^{(26)}$. We emphasize that this study assessed this occurrence at elderly people's homes using a specific data collection instrument to track down violence.

However, this methodology differs from that used in this study, which analyzed the formalized record of violence at the Police Station, Elder Abuse Department, a public institution that records complaints of violence and intervenes in abusive cases with a view to complying with legislation at the municipal level. Despite the limitations regarding the underreporting of violence, we infer that our findings contribute to a diagnosis of the municipality's situation, since the police station is an appropriate place to formalize cases of elder abuse.

Consubstantiating this situational diagnosis, using geoprocessing becomes an important instrument for understanding violence and, therefore, contributes to public policy management. It is in this context of debate that spatial representation of violence using the Geographic Information System, considered essential to identify high-risk areas, raises reflections on the need for reform in the social justice sector ${ }^{(25)}$.

Violence can be considered a public health problem, given the multidimensionality of the determinants that enhance its occurrence. The scientific literature has shown that ecological aspects such as ethical, political, cultural and social issues in each context can interfere with the occurrence of this event ${ }^{(25)}$.

This data supports the present investigation, as it shows spatial dependence on distribution per occurrence up to a distance of $5,000 \mathrm{~m}$ from their places of residence. However, a divergent result was found in a retrospective survey of American elderly people, as the authors identified a low correlation between place of violence between elderly people and neighborhood ${ }^{(27)}$. Although elder abuse is a global phenomenon ${ }^{(19)}$, we do not consider it pertinent to disregard its relationship with cultural and social contexts ${ }^{(19,}$ 22), which justifies the divergence among data.

In Brazil, prejudice against elderly people stems from the concept of old age being a phase of inactivity, in which there is a lack of learning capacity, which favors oppression and discrimination to spread ${ }^{(23)}$. Despite institutional mechanisms to prevent and report elder abuse, in practice they are not effective in ensuring adequate protection for these people ${ }^{(28)}$. However, data suggest that elderly people have also sought more the police station to record the occurrence, as evidenced in a study that identified an increase in the number of records of violence over the years ${ }^{(21)}$.

It is important to highlight that the police station is an embracement space for elderly victims of aggression; therefore, in addition to formally registering the event, it needs to be articulated with health and social services sectors to make the necessary referrals and, consequently, strengthen social justice. Thus, nurses must, during assessment of elderly people both in health services and at home,

to detect risks of violence to propose integration between the health service and social justice and, therefore, early intervention. 


\section{Study limitations}

This study has the following potential limitations: a) type of ecological study design, which does not allow individual inferences; $b$ ) underreporting of violence due to the difficulty of dependent elderly people to go to a place of notification and even for not knowing that there is a proper place for this; c) lack of standardization of information recorded in police reports by service professionals as well as underestimated and incomplete record of secondary data.

\section{Contributions to nursing, health, public policies}

The data of this research, obtained through GIS and spatial analysis use, contribute to dimension especially the elder abuse behavior in Ribeirão Preto, besides providing elements to subsidize the conception and management of intersectoral health strategies. We reiterate that violence is a public health problem that affects elderly people' social and family lives, who are considered more vulnerable.

The family environment must be analyzed and public policies must propose and implement social support for families and elderly people. It is in this context that the health sector, through health professionals, must be prepared to assess elderly victims of violence, both during care in health services and during home visits.

\section{CONCLUSION}

We found a higher rate of violence records among elderly men, aged 60 to 70 years and without a partner. In Moran's I analysis, when analyzing the event location, we identified that the spatial correlation of high clusters of elder abuse was concentrated in the city center; however, in an analysis by place of residence, it was present in all regions. Finally, more than $80 \%$ of cases of violence analyzed ran at elderly people's own homes and with spatial dependence on distribution by occurrence up to a distance of 5,000 $\mathrm{m}$ from their places of residence.

\section{FUNDING}

This study was funded by the National Council for Scientific and Technological Development - CNPq, Universal- process number 458701/2014-9.

\section{REFERENCES}

1. United Nation. World Elder Abuse Awareness Day 15 June [Internet]. 2017 [cited 2018 Jul 25]. Available from: http://www.un.org/en/events/ elderabuse/

2. World Health Organization. Global status report on violence prevention: 2014[Internet]. 2015 [cited 2018 Jul 25]. Available from: http:// www.undp.org/content/dam/undp/library/corporate/Reports/UNDP-GVA-violence-2014.pdf

3. Souza ER, Minayo MCS. The insertion of the violence against elderly theme at health care public policies in Brazil. Ciên Saúde Coletiva. 2010;15(6):2659-2668. doi: 10.1590/S1413-81232010000600002

4. Yon Y, Mikton CR, Gassoumis ZD, Wilber KH. Elder abuse prevalence in community settings: a systematic review and meta-analysis. Lancet Global Health. 2017;5(2):147-56. doi: 10.1016/S2214-109X(17)30006-2

5. Castro VC, Rissardo LK, Carreira L. Violence against the Brazilian elderlies: an analysis of hospitalizations. Rev Bras Enferm. 2018;71(suppl 2):777-85. doi: 10.1590/0034-7167-2017-0139

6. Paiva MM, Tavares DMS. Physical and psychological violence against the elderly: prevalence and associated factors. Rev Bras Enferm. 2015;68(6):1035-41. doi: 10.1590/0034-7167.2015680606i

7. Bolsoni CC, Coelho EBS, GiehI MWC, d'Orsi E. (2016). Prevalence of violence against the elderly and associated factors - a population based study in Florianópolis, Santa Catarina. Rev Bras Geriatr Gerontol. 2016;19(4):671-682. doi: 10.1590/1809-98232016019.150184

8. Rede Interagencial de Informações para a Saúde (BR). Sistemas de informação geográfica e a gestão da saúde no município. SD [cited 2018 Aug 12]. RIPSA; 25 p. Available from: http://www.ripsa.org.br/lildbi/docsonline/get.php?id=006

9. Bongiolo RS. Uso de sistemas de informação geográfica na saúde pública. Rev Olhar Cien [Internet]. 2010 [cited 2018 Jul 25];1(2):185-94. Available from: http://www.olharcientifico.kinghost.net/index.php/olhar/article/viewFile/23/31

10. Carnasciali AMS, Bulgacov S. Distributed resources and organizational skills in public health. Rev Adm Contemp. 2014;18(6):832-853. doi: 10.1590/1982-7849rac20141664

11. Bordin M, Lima RP. Mapeamento do crime e análise criminal: a experiência do Estado do Paraná. Rev Geografares. 2012;10:156-175. doi: 10.7147/GEO10.1666

12. Daura SP, Felix AS. Construindo novas metodologias para a espacialização dos indicadores sociais: o caso de Marília/SP. Rev LEVS [Internet]. 2009 [cited 2018 Jul 25];3. Available from: http://www2.marilia.unesp.br/revistas/index.php/levs/article/view/1096

13. Sousa DCB, Pitombo CS, Rocha SS, Salgueiro AR, Delgado JPM. Violence in public transportation: an approach based on spatial analysis. Rev Saúde Pública. 2017;51:127. doi:10.11606/s1518-8787.2017051007085

14. Stoler J, Verity J, Williams JR. Geodemographic disparities in availability of comprehensive intimate partner violence screening services in Miami-Dade County, Florida. J Interpers Violence. 2017. doi:10.1177/0886260517698283

15. Instituto Brasileiro de Geografia e Estatística. IBGE Cidades [Internet]. 2019 [cited 2018 Aug 12]. Available from: https://cidades.ibge.gov.br/ 
16. Presidência da República (BR). Lei $n^{\circ} 10.741$ de $1^{\circ}$ de outubro de 2003, Estatuto do idoso [Internet]. 2003 [cited 2018 Aug 12]. Available from: http://www2.camara.leg.br/legin/fed/lei/2003/lei-10741-1-outubro-2003-497511-publicacaooriginal-1-pl.html

17. Honorato T, Lapa PPA, Sales CMM, Reis-Santos B, Tristão-Sá R, Bertolde Al, et al. Spatial analysis of distribution of dengue cases in Espírito Santo, Brazil, in 2010: use of Bayesian model. Rev Bras Epidemiol. 2014;17(Suppl. 2):150-9. doi: 10.1590/1809-4503201400060013

18. Ruelas-González MG, Duarte-Gómez MB, Flores-Hernández S, Ortega-Altamirano DV, Cortés-Gil JD, Taboada A, et al. Prevalence and factors associated with violence and abuse of older adults in Mexico's 2012 National Health and Nutrition Survey. Int J Equity Health. 2016;15:35. doi:10.1186/s12939-016-0315-y

19. Dong, X. Do the definitions of elder mistreatment subtypes matter? findings from the PINE Study. J Gerontol A Biol Sci Med Sci. 2014;69(Suppl 2):S68-S75. doi: 10.1093/gerona/glu141

20. Government of Canada. Crime and abuse against seniors: a review of the research literature with special reference to the Canadian situation [Internet]. 2015 [cited 2018 Aug 12]. Available from: http://www.justice.gc.ca/eng/rp-pr/cj-jp/fv-vf/crim/sum-som.html

21. Rodrigues RAP, Monteiro EA, Santos AMR, Pontes MLF, Fhon JRS, Bolina AF, et al. Older adults abuse in three Brazilian cities. Rev Bras Enferm. 2017;70(4):783-791. doi:10.1590/0034-7167-2017-0114

22. Dong $X$, Chen R, Fulmer T, Simon MA. Prevalence and correlates of elder mistreatment in a community-dwelling population of U.S. Chinese older adults. J Aging Health. 2014;26(7):1209-24. doi: 10.1177/0898264314531617

23. World Health Organization (WHO). Elder abuse [Internet]. 2018 [cited 2018 Aug 12]. Available from: https://www.who.int/news-room/ fact-sheets/detail/elder-abuse

24. Bramanti A, D'Aloja E, Cabras F, Paribello P, Moro MF, Lindert J, et al. The elderly and the city: lack of knowledge on violence perception and consequences on daily life. Clin Pract Epidemiol Ment Health. 2018;14:46-52. doi:10.2174/1745017901814010046

25. Lasecki CH, Mujica FC, Stutsman S, Williams AY, Ding L, Simmons JD, et al. Geospatial mapping can be used to identify geographic areas and social factors associated with intentional injury as targets for prevention efforts distinct to a given community. J Trauma Acute Care Surg. 2018;84(1):70-4. doi: 10.1097/TA.0000000000001720

26. Belisário MS, Dias FA, Pegorari MS, Paiva MM, Ferreira PCS, Corradini FA, et al. Cross-sectional study on the association between frailty and violence against community-dwelling elderly people in Brazil. Sao Paulo Med J. 2018;136(1):10-19. doi: 10.1590/1516-3180.2017.0203290817

27. Baines A. Risk factors for Elder abuse mapped across Pennsylvania counties: can we determine areas of need? [Internet]. St. Mary's College of Maryland, University of Pittsburgh. 2017 [cited 2018 Aug 12]. Available from: http://d-scholarship.pitt.edu/31207/1/BainesAE_ ETD_4_2017.pdf

28. Roepke-Buehler SK, Dong X. Perceived stress and elder abuse: a population-based study of adult protective services cases in Chicago. J Am Geriatr Soc. 2015;63(9):1820-1828. doi: 10.1111/jgs.13613 